\title{
Contemporary City as a Subject of Research: A Multi-faceted Analysis
}

\author{
I. Kapsa, A. Kaszkur and K. Sierzputowska \\ Institute of Political Science, Kazimierz Wielki University in Bydgoszcz
}

\begin{abstract}
The article presents a research proposal based on the analysis of three aspects of urban policy and the interaction of authorities with citizens. It points to public innovations as tools contributing to expanding the field of activity of city dwellers; the concept of e-politics and its importance for the development of bilateral communication between residents of the city and the institution of power; the issue of conflict as an indicator of civic interactions, establishing relationships and undertaking various forms of activity. This research addresses issues related to participatory management instruments, city development prospects and forms of co-deciding about it. Keywords: city; conflicts; e-politics; new media; public innovations.
\end{abstract}

\section{Introduction}

Intense urbanization, global competition in economy and technological advances have caused cities to become the centres of social life in our modern world. Their growth proves to be challenging for local authorities, entrepreneurs and citizens. Cities of the future are being created for the generation 2.0. This process requires a large amount of creativity and determination based on close cooperation between citizens, municipal authorities and providers of certain technologies (Kapsa, 2017, p. 82).

In the resent article the modern city is treated not only as a living space for its citizens but also as a subject of politics. As far as the latter is concerned, we concentrate on the citizen-authority relationship in which many interesting challenges and changes may be observed, especially in the wake of digitalization. That is why we point to public innovations as tools contributing to expanding the field of activity of city dwellers. Then we introduce the concept of e-politics and its importance for the development of bilateral communication between residents of the city and the institution of power. We also claim that technology has mobilization potential, but also causes polarization, because it strengthens social divisions. This, in turn, brings us to the issue of conflict as an indicator of civic interactions, establishing relationships and undertaking various forms of activity. At the same time we see conflict as an essential growth potential of cities.

The aim of the present article is to present the multi-aspect political science-oriented perspective on the city as a space of activity for their citizens as well as an area of political actions for the local authorities. This perspective involves researching such issues as political participation, electronic political communication and local conflicts, which we analyse in the context of city's growth. We observe the significant importance of these aspects both in terms of research as well as the practical use of knowledge of modern cities.

\section{Research perspectives on modern cities}

The majority of studies conducted regarding cities, especially in the political sciences, fails to define the city as a subject of research. Researchers usually refer to the administrative status of cities, limiting the research problem to local government politics. Literature on the subject 
describes the city as a state of the soul and an amalgamation of traditions (Park, 1925), as a system (Castells, 1982), as a hub (Gorzelak, 2008), or refer to it in terms of a conflict between the villages and the state (Barber, 2013). Treating the city as a hub - a complicated economical-political network which enables a fully functioning modern society - allows us to look at it as a form of economic, political, administrative and communicative system, embedded in a certain space and influencing that space, sometimes far beyond its administrative borders (Matyja, 2017, p.13). The modern city should be considered from the point of view of the tendency that appeared in the recent decades to move from and industrial city to a post-industrial one and its social consequences as well as in terms of a clear distinction between a city and a metropolis (Węcławowicz, 2007).

Our approach encourages the use of a multi-aspect approach to researching the city as a living space for its citizens who participate, accept the decisions of authorities and form the local identity and community. In our view, the city is also an area of political activity for the local authorities with a legally defined set of competencies and election-authorized influence on the type of relations with private and public entities in the region and the state. In this sense we treat the city in a much broader sense than the previously known concepts, recognising that only a holistic analysis of phenomena and processes on the city level will enable their proper understanding and practical use.

\subsection{Public innovation as a means of strengthening civil activity of city dwellers}

The idea of giving every citizen the chance to participate lies at the heart of democracy. However, in the representative democracy it is difficult to say that the participation of citizens or their influence on the actions of state institutions are real. An antidote for this state of affairs is seen in attempts to increase the influence of citizens on the public life on the local level. Using innovative participation tools and changing the model of managing cities, evolving it towards co-management, arguably seems to be the more popular choice. By betting on the increase of civic activity and including citizens in the co-management processes, one does not only create the possibility to free their creativity, but most importantly to realize the city's growth potential.

The development of new technologies and their use in almost every aspect of human activity also contribute to their absorption in the public sphere. Importantly, the public sphere also cocreates innovations, both in terms of technologies and new reforms and instruments of public management. Simultaneously, the public sector creates an innovative environment, contributing to the broadly understood growth (Wiktorska-Święcka, Kozak, 2014, p. 77).

By public innovation we mean the ability to generate innovations and/or the process of creating them in the sphere of dialogical and open social interactions, the essential feature of which is the realization of articulative, normative and inclusive functions. Thus, it comes down to the activities of entities operating in the public sphere. These consist of searching and utilising the results of scientific research, new concepts and ideas, methods and techniques used in a given organization, as well as improving its infrastructure and the quality of its services and products (Laska, 2017, p. 19).

Openness of public institutions to innovations also entails greater possibilities in terms of civic participation. New ICT technologies enable a plethora of possibilities, for example in terms of including citizens in co-management processes, solving conflicts or access to public information. The Internet may function as a peculiar form of agora - a place of unhampered public debate and sharing one's views and experiences.

Electronic consultations are among the innovative forms of participations. The ease of access, low time-related requirements in organizing such consultations and the ability of immediately sharing their results are doubtlessly their biggest advantages. This form of running consultations also requires less financial investment when compared to the more traditional forms. Importantly, 


\section{药 \\ $5^{\text {th }}$ International Conference on Research in \\ Behavioral and Social Science \\ Spain | Barcelona | December 7-9, 2018}

the wide accessibility of databases increases the relevance of e-consultations because it is much harder for the authorities to ignore archived and publicly available opinions of citizens (Mider, 2008, p. 228-229, 232). ICT technologies are also used to transmit traditional consultations.

Among the most interesting solutions that enable discussions in moderated groups are Planning Cells, Citizen Jury, Citizen's Panels, technological panels and DNA Miasta. Thanks to these methods citizens may take part in public decision-making and have a deeper understanding of affairs in a given community (Celiński, 2014, p. 158). In the initial stage of the participation process, where sharing knowledge and ideas is more important than coming up with a specific solution, The World Café method might prove to be quite effective. In conditions similar to that of a café, the participants discuss certain issues until the moderator tells them to switch places (http://www.theworldcafe.com/). This method primarily helps raise awareness of certain topics and fosters greater engagement, which is especially important in the early stages of consultations.

Participatory budget is an interesting form of opening up the public authority to the citizens. It gives citizens the opportunity to co-create a given city's budget by including them in the decisionmaking process in terms of distributing certain amounts of public funds. Its integral part is discussion. Also the authorities may gain information on the needs and expectations of the citizens, broadening the politicians' knowledge of how the city functions in reality and what problems its citizens are facing. This tool also promotes active participation of citizens and strengthens their trust in the representatives of the local government (Kłebowski, 2013, p. 8, 14). It is noticeable that more and more ICT technologies are being used during the creation of participatory budgets. Citizens may submit their proposals via official websites of city halls and vote electronically at a later stage of proceedings.

In contrast, city foresight is an innovative method used to create long-term development plans of a city. It does not serve to unequivocally predict the future but to create possible scenarios of events. This is done based on data and trend analyses and dialogue with experts, i.e. local authorities and representatives of businesses, culture, education, media and the third sector. Citizens are also welcome to cooperate and their opinions have a significant impact on the developed scenarios (Czajor et al, 2015, p. 9).

Public administration successively opens up its resources as well. Data openness is closely related to the possibility of sharing knowledge and, by extension, the quality of decisions included in the process of co-managing the citizens' local affairs.

However, by looking at the above examples of using innovations in the public sphere one can already observe that innovation not always entails the use of new technologies. Public innovations in terms of participation may thus constitute any original solutions that rely on co-participation of citizens and include them in the decision-making and, most importantly, activating processes, both in a new, never before used way, as well as through improved participation solutions (Kaszkur, 2017 , p. 74). However, there is no doubt that the scope of using new ICT technologies in the public sphere will be getting broader and broader. Nevertheless, for the citizens to use the abilities given to them by new technologies, especially in terms of citizen participation, their need for conducting such activities has to be elicited. This will not be possible without political socialization. First, citizens need to be given access to accurate knowledge of politics and its processes. This in turn enables the use of new ICT technologies that are successfully used as political communication tools.

\subsection{E-politics on the city level}

E-politics is one of the notions that appeared at the beginning of the 21st century in order to name new tools, processes, procedures, phenomena and actions within the scope of democracy (e- 
democracy) and many narrower notions (ex. e-government, e-voting, e-participation), created due to the use of ICT technologies. E-politics also entails the use of electronic technologies in politics and as such fits into the notion of e-democracy, which is based on two pillars. The first of them encompasses interactions of citizens and various (governed) groups via the web, not only among themselves, but also with political elites. The second one relates to the activity of politicians, ruling parties and authorities (Lakomy, 2013, p. 188). If we consider the fact that information is the most essential web resource in the modern society, the influence on information is fundamental for administration. In this context e-politics indicates that political elites take action on the basis of using new media as a tool of political communication (if the tool in question is Web 2.0, we refer to the notion of Politics 2.0). The evolution of the Internet as the basic medium of modern communication, being not only an instrument for sharing content, but an interactive polyphonic platform of open debate, caused that the familiar democratic model has been enriched both by new tools and social groups engaged in democratic processes.

Nowadays a peculiar feedback loop between the citizens and authorities may be observed. As a result, there is an emergence of new delivery techniques and public service types and the aforementioned forms of civic participation which fundamentally change the nature of political communication between these parties. Many interpretations of participatory democracy point out to the fact that the local level fosters growth of civic participation and cities should pioneer in this regard. Both scientific publications and organizational reports prove that there is a rising interest in civic engagement and political participation in the new established concept of "local governance". In the mid-2000s, the International City/County Management Association (ICMA) launched a project to identify practices that professional local government administrators bring to their communities. It argues that citizen engagement is no longer optional - it is imperative - and that connecting engagement initiatives to traditional political values and governing processes is an important mark of successful community building (Nalbandian et al., 2013, pp. 567-574). This implies the need to integrate citizen engagement and other forms of engagement (planned and spontaneous, including social media) with traditional local government structures and processes. In order to fulfil this task it is important to communicate the world of politics with the social world as the modern local community is formed mostly by communication. In terms of local actions, the most broadly perceived one is the chance for greater responsiveness of representatives of local authorities to citizens. The most repeatedly discussed notion here is the argument of scale and size of groups in which a conclusive debate is still possible (Przybylska, 2010, p. 10). Piotr Siuda (2018) states that the modern Internet is based on locality. Thereby he opposes everyone who perceived the Internet as a source of dwindling social ties. Siuda claims that the Internet changes the character of ties between people - using new technologies, we alter the way how we interact with each other in a cityscape. Internet contacts are based on weak ties, sustained only through the use of communication tools. However, it is often the only type of tie one might have in a city (except for strong family bonds). Nonetheless, considering that democracy is aided by nonhierarchical communication relations with a possible node in the form of information-related actions of the local government, the Internet fulfils such a need. Of course, the availability of tools enabling interaction alone does not decide that relations of authorities become more horizontal. The opinions of citizens gathered from many sources should also be included in the decision-making process (Przybylska, 2010, p. 229).

In the concept of e-politics and its importance for the development of bilateral communication between a citizen and an institution of power, e-politics is realized both by public institutions and outside of them. In the first case, an interesting example of a research project created with the aim of enabling local community members to participate in debates regarding issues that influence them directly and have access to information is the Virtual Town Square (http://vts.cs.vt.edu/research). 
It is an aggregator in the form of a web platform which gathers relevant content and presents it to users depending on their preferences. Its aim is to increase the engagement of citizens in local affairs and foster social interaction between users with common characteristics: their place of residence, interests and activities. Instead of creating a new website filled with random content, its authors want to focus on the community with content controlled by the users (Kavanaugh, et al., pp. 36-54). On the institutional level there are also few examples of positive use of technology in the process of political decision-making. The most robust platform used in Germany is LiquidFeedback (http://liquidfeedback.org). This platform serves the local community members (in Friesland) as a tool to relay proposals and indicate the political direction of the region. These are then put to a vote by all the users of the system. The application also servers an informative function - local authorities use it as a means of informing citizens of their decisions.

The electronic system of information and public services called e-government is a different institutional dimension of e-politics. In e-government (also on local level), the government uses information technology and particularly the Internet to support government operations, engage citizens, and provide government services (Palvia, Sharma, 2007, p. 1). The definition used by the United Nations (www.unpan.org) also points out to exceptional participation of citizens in the creation of e-government. It is defined as utilizing the Internet and the world-wide-web for providing government information and services to citizens. Government to citizens (G2C) are those activities in which the government provides one-stop, on-line access to information and services to citizens (Backus, 2001). Some of them are only limited to providing information (one-way communication), for example general information such as mission statements and organizational structure, addresses, opening hours, employees, telephone numbers, laws, rules and regulations, petitions, government glossary, news. This type of information is provided via city hall platforms that also enable offering public services (in the form of interactions) such as filling out on-line forms in order to get an ID card, statements of birth or death, registering cars, registering to a job centre, obtaining geodesic materials or building permits or handling electronic tax declarations. Public information is also delivered via e-mail or newsletters. Moreover, Intelligent Transportation Systems exist which relay information to citizens regarding traffic and obstructions in public transport. The communication is two-way (e.g. personalised website with an integrated personal account for all services), both in the process of interaction and transformation. It also takes place during social consultations or the creation of participatory budgets in which the citizen takes part in the political decision-making process. As indicated in the OECD report "Citizens as Partners" (2001), e-government is related to citizens' participation in the public debate. It must involve the means to be informed, the mechanisms to take part in the decision-making and the ability to contribute and influence the policy agenda. This is done on three levels: information, consultation and active participation. The use of these tools is measured by reports of international organizations (e.g. United Nations E-Government Survey) which show that most developed countries use electronic tools to provide information and public services. The level of their use is diversified and depends on many factors (legal bases, access to technologies, civic competencies, openness of authorities, etc.). In terms of civic politics better engagement of citizens in the policy-making process indeed contributes to producing better quality policies, building trust and gaining acceptance of policies as well as sharing responsibility for policy-making (OECD report 2003, p. $33)$.

\subsection{City research from the perspective of conflict}

The city is a complex social system preconditioned by interdependent relations which form the basis of efficient operation and the foundation of antagonisms and conflicts. This kind of social 
situation, in which there are confrontations due to conflicting interests, attitudes or even values of individuals, is not only unavoidable but also necessary. It often plays the role of a stimulator of a city's growth, supporting its effective functioning and raising its efficiency. This means that according to the functional theory of conflict, it may be deemed as a normal phenomenon and its complete elimination from the social life might even be harmful. Thus some research orientations consider conflict as an inherent component of public or "subdermal" life of each city (Broniewska, 2015, pp. 83-85). However despite the prevalence of conflicts and resulting changes, it should be noted that these phenomena are not exclusively destructive. This was pointed out by Lewis A. Coser, among others. He primarily analysed those consequences of conflict that contribute to better adaptation of certain groups (e.g. city movements) or positive changes in social relations (Coser, 1956). According to Coser, conflict is not just a negative factor which divides people. It might also play an integrative function, which helps in keeping group bonds and strengthening integration of group members (Kotarba, 2008). Ralf Dahrendorf, and earlier Karl Marx, put great emphasis on the destructive consequences of conflict. Meanwhile, Lewis A. Coser highlights primarily the integrative and adaptive functions of conflict for social systems (e.g. cities). He sought sources of conflict in aspirations of individuals rather than in the attributes of social structures. Conflicts, as a social phenomenon, perform certain important functions. They cause specific actions and various effect. Therefore conflict may also perform a series of positive functions for cities. If it is constructive, it might be an organizational instrument leading to desirable changes and innovations. In the broader perspective a conflict situation might be an impulse for growth. It is however necessary to skilfully manage conflict. This may result in implementing concepts in the form of farreaching growth-related initiatives, urban strategies or competitive and innovative solutions (related to IT, communication, spatial planning, etc.). Thus conflict should be understood both as a threat and as a chance to improve the way the city functions. The conflict resulting from the activity of cities may be constructive. In order for this to happen, one of the basic requirements related to management must be met. This primarily entails concentrating on current problems, not on past events; on facts, not on intentions and on the essence of a problem, not on personality traits. Only then can conflict management result in giving it a positive direction. Constructive communication forms the basis of these changes, as proper feedback might build a culture of action among the entities operating in the public sphere (Broniewska, 2015).

When researching the problem of conflicts on the scale of the local government, it is worth basing it on the concepts introduced by R. Dahrendorf, L. Coser and R. Collins. The local government not only plays an administrative role, but also acts as a local authority and thus a local political scene. Among the many definitions of politics, even in the functional orientation, "it is understood as a function of the social system, enabling growth through: resolving conflicts; creating decisions that authoritatively regulate the division of goods [...]" (Antoszewski, Herbut, 1995, p. 296). Ralf Dahrendorf in his conflictual model of society points out that every society undergoes constant changes, that discord and conflict are its universal parts and that each one's mechanism of action is based on coercing one group by a another group (Dahrendorf, 2008, pp. 146-153).

The precisely outlined scope of administrative rule, institutions of municipal authorities and a universally understood range of competencies form a natural - as it might seem - political arena in which power struggles and ruling practice may be observed. We observe and may effortlessly describe the changes in the social composition of elites, the emergence of new trends in public management, organizing new interest groups, etc. The various conflicts of interest that occur in such situations might not necessarily lead to interpersonal conflicts, but might pave the way to positive changes. When analysing the issue of social conflicts. Dahrendorf paid special attention to the element of authorities. According to him, one of the most important conflict-generating areas 
are commonly occurring dependencies. "Each position in an imperatively coordinated group might be assigned to someone who rules or who is being ruled" (Dahrendorf, 2008).

Irrespective of the way in which local authorities are created, the shape of the local political system and its functioning, control over this system relies on making various decisions which enable reaching a state of balance in spite of various disturbances and conflicts (Kotarba, 2008, pp. 279-294). These conflicts in urban environments results mainly from expectations and needs of different interest groups as well as the lack of ability to meet all these expectations by the elites.

Preconditioned by deep economical and socio-political transformations, the management of urban development resulted in modifications to the methods and ways of operating on the local level. The fundamental change of the urban politics resulted in an alteration of logic in the realization of tasks connected to urban development and solving the city's problems (Sagan, 2009, pp. 73-75). The increasing number of entities that co-govern the city (non-government entities), the rising activity of social movements and a sudden accretion of diversified entities in the local scene have consequently led to the fragmentation of the municipal political scene as well as exposure of numerous particularities and conflicts of interest. However, one fact remains unchanged - politics, no matter if it is local, national or local, remains an area of confrontation and antagonistic tension. According to the conflictual vision of Chantal Mouffe (2008, pp. 24-35), it is "a space of authority, conflict and antagonism (...). Theorists who wish to free politics of passion by introducing reason, moderation and consensus, do not understand the dynamic nature of diplomacy". In her opinion, all sides of a conflict must be connected by some kind of bond which will not let any of the parties see their rivals as fierce enemies that should be eliminated. Mouffe thus deems that politics, as "a set of practices and institutions that introduce a certain order in conflict", has the goal to transform an antagonistic conflict into an "agonic" one where sites are "competitors" and "rivals", but not enemies. This means that despite a contentious relation, all sides perceive each other as belonging to the same political association and sharing the same symbolic universe". This is why creating new identifications may lead to potential social changes, invigorate the citizens' interest in politics and rebuild their trust to political institutions and politicians (Morawski, 2012, pp. 191-193).

\section{Summary}

Nowadays, while managing urban development still formally lies within the responsibility of local governments, it is to large extent initiated, supported and modified by the local community. It consists of supporting internal development processes, i.e. stimulating growth from within by providing support from the outside, which facilitates the use of innovative local solutions (Miasta przyszłości, 2011). Similar to all the other instruments and methods based on substantial citizen participation and grass-roots engagement, local development depends on the skills of participating entities. However, because it concerns a relatively small group of people and a limited area, it reflects the specific features of a given local community as well as the cultural, economic and political conditions in the city. Therefore, it seems that studying these processes requires a wider perspective as well.

The choice of research perspectives presented in the present article is indicative of the fact that a certain feedback loop may be observed in the development of modern cities. The factors contributing to urban development are at the same time reinforced by the development itself. The same phenomenon can be observed in the field of public innovations (participation) as well as epolitics or local conflicts. Thus only a multi-faceted analysis may help identify and investigate the processes taking place in today's cities. 


\section{References}

Antoszewski A., Herbut R.: Leksykon politologii, Wyd. UWr, Wrocław 1995.

Backus M.: "E-Governance and Developing Countries, Introduction and examples", Research Report, No. 3, April 2001.

Barber B.R.: If Mayors Ruled the World: Dysfunctional Nations, Rising Cities, Yale University Press, New Haven 2013.

Broniewska G.: "Zarządzanie konfliktem jako istotna kompetencja współczesnego menadżera", Studia Ekonomiczne Regionu Łódzkiego, No. 17, 2015.

Castells M.: Kwestia miejska, PWN, Warsaw 1982.

Celiński A.: "'DNA Miasta' jako narzędzie partycypacji społecznej", Przybylska A., Giza A., Partycypacja obywatelska. Od teorii do praktyki społecznej, Scholar, Warsaw 2014.

Citizens as Partners. OECD handbook on information, consultation and public participation in policymaking, http://www.oecdilibrary.org/docserver/download/4201141e.pdf?expires=1466419296\&id=id\&accname=guest\&checksu $\mathrm{m}=50579937619786 \mathrm{FC} 1861 \mathrm{ED} 877 \mathrm{D} 958 \mathrm{~F} 75$

Coser L.A.: The Functions of Social Conflict, The Free Press, New York 1956.

Czajor M., Koszewska M., Król J., Kuźmińska A., Słupiński M.: Jaka przyszłość czeka Konin? Foresight miejski, Konin, content/uploads/2018/06/Konin2050_raportko\%C5\%84cowy-1.pdf.

Dahrendorf R.: Klasy i konflikt klasowy w społeczeństwie przemysłowym, NOMOS, Kraków 2008.

Gorzelak G.: "Miasto jako przedmiot badań ekonomii", Jałowiecki B., Miasto jako przedmiot badań naukowych w początkach XXI wieku, Scholar, Warsaw 2008.

Kapsa I.: "Elektroniczna partycypacja obywatelska w miastach typu 'smart'. Doświadczenia Polski na tle innych państw", Kaszkur A., Laska A., Innowacyjność w warunkach współczesnych miast, Wyd. UKW, Bydgoszcz 2017.

Kaszkur A.: "Innowacyjne formy partycypacji politycznej na poziomie lokalnym w Polsce", Kaszkur A., Laska A., Innowacyjność w warunkach współczesnych miast, Wyd. UKW, Bydgoszcz 2017.

Kavanaugh A., Krishnan S., Pérez-Quiñones M., Tedesco J., Madondo K., Ahuja A.: "Encouraging civic participation through local news aggregation", Information Polity, vol. 19, 2014.

Kotarba B.: "Wpływ konfliktów w samorządzie gminnym na zachowanie spójności społeczno-ekonomicznej gminy", Nierówności Społeczne a Wzrost Gospodarczy (Social Inequalities and Economic Growth), No. 13, 2008.

Lakomy M.: Demokracja 2.0. Interakcja polityczna w nowych mediach, Akademia Ignatianum, Kraków 2013.

Laska A.: "Innowacyjność publiczna - próba konceptualizacji pojęcia", Kaszkur A., Laska A., Wyzwania innowacyjności w sferze publicznej, Wyd. UKW, Bydgoszcz 2015.

Matyja R.: "Miasto jako przestrzeń, węzeł i system. Analiza z perspektywy badań politologicznych", Acta Politica Polonica, No. 3 (41), 2017.

Miasta przyszłości. Wyzwania, wizje, perspektywy, (2011), http://ec.europa.eu/regional_policy/sources/docgener/studies/pdf/citiesoftomorrow/citiesoftomorrow fin al_pl.pdf

Mider D.: Partycypacja polityczna w Internecie. Studium politologiczne, Elipsa, Warsaw 2008.

Morawski K.: "Laclau i Mouffe — teoria polityczności", Czajowski A., Sobkowiak L., Polityka $i$ polityczność. Problemy teoretyczne i metodologiczne, Atla 2, Wrocław 2012.

Mouffe Ch.: Polityczność. Przewodnik krytyki politycznej, Wydawnictwo Krytyki Politycznej, Warsaw 2008.

Nalbandian J., O’Neill R. Jr., Wilkes J.M., Kaufman A.: "Contemporary Challenges in Local Government: Evolving Roles and Responsibilities, Structures, and Processes", Public Administration Review, Vol. 73, Iss. 4, 2013.

Palvia S. C. J., Sharma S. S.: E-Government and E-Governance: Definitions/Domain Framework and Status around the World, $5^{\text {th }}$ International Conference on E-governance (ICEG), 2007.

Park E.R., Burgess E.W.: The City. Suggestions and Investigation of Human Behavior in the Urban 
$5^{\text {th }}$ International Conference on Research in

Environment, The University of Chicago Press, Chicago 1925.

Przybylska A.: Intenet i komunikowanie we wspólnocie lokalnej, Wyd. UW, Warsaw 2010.

Sagan I.: "Polityka miejskiego współzarządzania. Walory koncepcji i ograniczenia praktyki", Gorzelak G.,

Szczepański M., Ślęzak-Tazbir W., Człowiek - miasto - region. Związki i interakcje, Scholar, Warsaw 2009.

Siuda P.: Internet nie zabija lokalności, ale ja ożywia, https://www.kongresobywatelski.pl/idee-dla-polskikategoria/internet-nie-zabija-lokalnosci-ale-ja-ozywia/?fbclid=IwAR3SZpbqVSQFqrkoo4Bx5C0-

K4YdVunCbSc2hc3EmP_Sxh9xt7yEmlbRFNc

Węcławowicz G.: Geografia społeczna miast, PWN, Warsaw 2007.

Wiktorska-Święcka A., Kozak. K.: Partycypacja publiczna w zarządzaniu rozwojem lokalnym, Atut -

Wrocławskie Wydawnictwo Oświatowe, Wrocław 2014. 